\title{
Speaking for Others: The Pros and Cons of Group Advocates using Collective Language
}

\author{
Matthew J. Hornsey and Leda Blackwood \\ University of Queensland
}

Anne O'Brien

University of Exeter

\begin{abstract}
We examined how rhetorical style affects evaluations of group advocates, and how these evaluations are moderated by group identification. University students were given a letter to the editor defending student welfare. The argument was either constructed using personal language ('I believe') or collective language ('we believe'). Furthermore, the letter was either attributed to an official advocate (president of the student union) or an unofficial advocate (a rank-and-file member of the student body). Consistent with the social identity perspective, participants who showed strong identification as a university student thought that the group would feel better represented by official advocates using collective rather than personal language. Low identifiers, however, did not rate the rhetorical styles differently on representativeness. Furthermore, low identifiers (but not high identifiers) rated official advocates as more likable and more effective when they used personal rather than collective language. The discussion focuses on the conflict low identifiers might feel between (a) needing to homogenize with other group members in order to maximize the influence and political effectiveness of their message at the collective level, and (b) protecting themselves against categorization threat.
\end{abstract}

KEYWORDS categorization threat, collective action, group advocates, language and intergroup relations

The Functioning of a liberal democracy is contingent on formalized processes for the representation of group-based interests. From the industrial shop-floor steward to the Head of State, our public and private lives are crossed by those who claim to speak for us-for our values and for our interests as defined by our group memberships. Effective collective action rests on the skills of these people to prosecute the interests of their groups and to achieve positive change.

\footnotetext{
Author's note

Address correspondence to Matthew Hornsey, School of Psychology, University of Queensland, St Lucia 4072, Queensland, Australia [email: m.hornsey@psy.uq.edu.au]
} 
The job of an advocate is complex because he or she has multiple audiences. One role of the advocate is to influence a rival group. Political conflict typically involves the struggle between groups for resources, power, and/or prestige, and success can be gauged by the extent to which the advocate can win concessions from relevant outgroups. But to achieve this goal, groups often have to win over the support of critical third parties (e.g. the general public). Many intergroup struggles are played out within this wider social context, and so one goal of the advocate might be to convince the general public of the legitimacy and importance of the group's claims (Simon \& Klandermans, 2001). In addition, advocates must be mindful of their internal audience (the members of the group that they represent). Indeed, the perceived success and longevity of an advocate depends crucially on how effective other group members think he or she is in terms of promoting change, and in accurately representing the group. In sum, the commonsense view would be that advocates are seen to succeed or fail on the basis of their ability to (a) credibly identify and prosecute the interests of a group; and (b) convince members of that group that they have done so.

The focus of the current study is on how advocates are evaluated by their internal audience; that is, other ingroup members. We examine how ingroup members evaluate those who represent their group's interests, and how these evaluations differ as a function of their identification with their group and the advocate's rhetorical style. Specifically, we examine whether it is more effective for an advocate to use collective language ('We believe') or to frame the argument as a personal attitude (' $I$ believe'). Using an experimental paradigm, we demonstrate below how choice of language and identification interact in theoretically predictable ways to affect the perceived likability, effectiveness, and representativeness of an advocate.

\section{Does the type of language matter?}

When attempting to persuade others of the legitimacy of a group's concerns, people have a choice as to what rhetorical style they use. On the one hand, they can emphasize the personal nature of the attitude (' $I$ believe') in the hope that their testimonial will help foster sympathy for the cause of the wider group. Alternatively, they can speak on behalf of the wider group ('We believe').

There is a convergence of theory and research that speaks to the appropriateness of the latter strategy when engaging in political action. For example, the use of collective language helps signal solidarity and unity which, according to research on minority influence, is fundamentally important when it comes to influencing the views of the majority (Maass \& Clark, 1984; Moscovici, 1976; Mugny \& Perez, 1991). By using collective language, the advocate indicates that the group feels certainty in, and strong commitment to, its message. This helps promote uncertainty and doubt regarding the issue in the minds of the majority and helps draw attention to the minority group as a coherent entity that deserves to be taken seriously. So, for outgroup audiences at least (e.g. the general public; rival groups), it can be expected that collective language will be more effective than personal language.

A second reason that collective language might be more effective is that it helps emphasize the ongoing loyalty and commitment of the advocate to their constituency (the ingroup members). In order to explicate the underlying mechanisms affecting this relationship, we turn to the social identity perspective on group processes. The basic premise of social identity theory (Tajfel \& Turner, 1979) and its extension, self-categorization theory (Turner, Hogg, Oakes, Reicher, \& Wetherell, 1987; Turner, 1991), is that an important part of our sense of self derives from the groups to which we belong (see Hogg, 2002; Turner, 1999, for recent reviews). According to this social identity perspective, the more strongly people identify with a salient group, the more they will depersonalize around the prototype of the group. Rather than relying on idiosyncratic attitudes, memories, and behaviors that distinguish themselves from other individuals (their 'personal identities'), high identifiers are more likely to converge to the collective attitudes, memories, and behaviors 
that define their group in opposition to other groups. Thus, according to the social identity perspective of leadership (Hogg, 2001; Turner \& Haslam, 2001), a highly prototypical leader does not need to be explicitly coercive in order to win support from other group members. Rather, by virtue of the fact that they represent the group prototype, influence will occur spontaneously and automatically as group members cognitively and behaviorally assimilate themselves to those features. Consistent with this, there is growing empirical evidence that leaders are seen to be more effective, likable, and fair the more they embody the attitudes and behaviors of the group prototype (Fielding \& Hogg, 1997; Hains, Hogg, \& Duck, 1997; Haslam et al., 1998; Hogg, Hains, \& Mason, 1998; Platow, Reid, \& Andrew, 1998; van Vugt \& de Cremer, 1999).

Social identities, however, are not static and tangible things; rather, they are highly contextual (e.g. Haslam, Turner, Oakes, McGarty, \& Hayes, 1992; Turner, Oakes, Haslam, \& McGarty, 1994). What represents the prototype of the group can shift depending on the intergroup context, and so leaders that encapsulate the defining features of the group in one context might be seen as less prototypical in other contexts. The challenge for leaders, then, is to manage their rhetoric such that they are continually adapting to the changing context and locating themselves as central members of the group. Through the strategic use of language, identities can be socially constructed, and to a degree, manipulated (e.g. Hopkins \& Reicher, 1996; Reicher \& Hopkins, 2001). For example, Reicher and Hopkins (1996a) described how an anti-abortionist's speech to a medical audience was managed in such a way that he claimed common ingroup membership with the audience. Others have described examples of politicians constructing their rhetoric such that their party is portrayed as representative of a broad national ingroup (Rapley, 1998; Reicher $\&$ Hopkins, 1996b). Given that people are typically more open to messages from ingroup than from outgroup speakers (Hornsey, Oppes, \& Svensson, 2002; Mackie, Worth, \& Asuncion, 1990), and that prototypical group members are typically seen to be more persuasive than peripheral group members (Hogg, 2001; van Knippenberg, Lossie, \& Wilke, 1994), such a strategy makes perfect sense.

One way to rhetorically emphasize common ingroup membership is to use collective language (e.g. 'we believe'). Indeed, Brewer and Gardner (1996) found that the mere process of priming the word 'we' was enough to increase the extent to which people used collective selfdescriptions. Collective language, then, might send out the message that the advocate is invested in and representative of the group, perceptions that are critical in gaining favor. In sum, the use of collective language is predicted to be effective in two ways: first, in terms of influencing outgroups, and second, in terms of winning over the trust and compliance of ingroup members.

Despite this, there might be some circumstances under which collective language would be rejected by group members. Speaking on behalf of the group assumes both homogeneity in the group and agreement about what the prototypical position is. In reality, this is rare; groups are not flat, undifferentiated entities. Although group members share at least one dimension in common (e.g. 'we are all women'), they may have different conceptualizations about what this identity means and different levels of commitment to the identity (Kelly \& Breinlinger, 1996). Furthermore, groups often embrace a diversity of subgroups defined by intragroup role assignments or by wider social category memberships (e.g. profession, socioeconomic status, ethnicity). These individual and subgroup differences can manifest themselves as internal struggles over status and the related power to define the group's values (Hornsey \& Hogg, 2000a, 2000b, 2000c, 2002; Mummendey \& Wenzel, 1999; Sani \& Reicher, 1998, 2000). So when an advocate speaks 'on behalf of the group', group members have the right to question just who within the group the advocate is representing.

\section{Does identification matter?}

One key difference that exists among members of groups is the degree to which they identify 
with the group. For some people, the group might be a fundamental part of one's selfconcept in that it is chronically accessible, it arouses positive affect, and it commands strong behavioral commitment. For others, though, the group might be something rarely thought about, and categorization as a member of the group might evoke little emotion, or even negative affect. For these low identifiers, the group does not form an important part of the selfconcept and there is little behavioral commitment to the group.

We would argue that the extent to which group members identify with their group is a key factor in moderating evaluations of collective and personal language. When an advocate uses collective language ('we'), they are essentially imposing a common or shared category on group members. By speaking on behalf of the group, advocates are sending out the message 'we are all group members, and we are all the same'. High identifiers might be perfectly happy to be categorized in this way, because such a categorization is consistent with their self-definition in that context. Low identifiers, however, might feel less comfortable with collective language, because the way they are being categorized is incompatible with their self-definition, resulting in resentment and discomfort.

In the language of the social identity perspective, the negativity associated with being categorized by others against one's will is called 'categorization threat' (Branscombe, Ellemers, Spears, \& Doosje, 1999). Categorization threat can emerge in two ways. First, people might feel discomfort if they are categorized in a way that is inappropriate for that context. For example, women may wish to be categorized as a professional at work, and feel threatened if they are instead categorized in terms of their gender (Branscombe \& Ellemers, 1998). Alternatively, categorization threat might be experienced if people are categorized as a member of a group that does not form an important part of the self-concept. For example, if being a university student is not an important part of a person's self-concept, then they might feel some level of resentment about being categorized as such
(Barreto \& Ellemers, 2002). Unlike most forms of threat, then, this form of categorization threat is assumed to be felt most keenly by low identifiers.

In sum, we argue that high identifiers are more likely to have assimilated to the norms, values, and attitudes of the group. As a result, they might be quite willing to be categorized as a group member, and to be seen by others in this way. In the absence of categorization threat, high identifiers might prefer collective over personal language (a) because it signals strength and cohesion to outgroups, and (b) because it signals to the ingroup that the advocate feels embedded within the wider group identity. In contrast, low identifiers might be more mindful of protecting their individual distinctiveness and might be more likely to feel they have been categorized against their will. For low identifiers, then, the preference for collective over personal language might be eliminated or even reversed.

\section{Does type of advocate matter?}

When operationalizing the research questions described above, one is faced with a critical question: What type of advocate are we talking about? Some advocates are 'official' representatives (e.g. politicians, activists, advocates, lobbyists) who have been employed or elected for the specific purpose of representing the interests of the group. But not all advocates play this role in an official sense. Sometimes, advocates are rank-and-file group members who have spontaneously decided to take political action: the concerned individual who fires off a letter to the editor or steps up to the megaphone at a rally. Although there is limited research relating to this question, it is possible that the choice of language might have different ramifications for official than for unofficial advocates.

As argued earlier, collective language might be beneficial for an advocate because it locates them as a central member of the group, thus potentially maximizing their influence. But it is reasonable to expect that this is not a mindless, hydraulic process; presumably people are capable of consciously weighing up the identity 
claims made by the advocate with the objective credentials of the speaker (see Hornsey \& Jetten, 2003, for a related discussion on impostors). At times, official representatives can be criticized for being too distant from the groups that they claim to represent. An official advocate (e.g. union leader, politician) often accrues power, prestige, and material reward over and above the intrinsic rewards associated with defending the group. As such, they are often depicted as having been seduced by their position and as having forgotten what it is like to be 'one of us'. Indeed, it is a paradox of the social identity model of leadership that the very process of being identified as a leader implies a separateness from followers, which in turn has the potential to 'sever the empathic intragroup bond' (Hogg, 2001, p. 195). At worst, our representatives may be seen as being of another group altogether-a reviled group of politicians or activists-who have one eye on serving their constituency and the other eye on serving their long-term individual career goals as advocates. For this reason, group members (particularly low identifiers) might feel relatively comfortable hearing collective language ('we believe') from a rank-and-file member who 'emerges' from the crowd and spontaneously takes on the role of fighting for the welfare of the group. In contrast, they might feel that an official advocate did not have the same entitlement to speak as though they share the experiences and aspirations of the group.

\section{The current experiment}

The current research aims to investigate the relationship between individuals' level of group identification and their evaluation of a group advocate who uses collective or personal language. In the study, university students read and evaluated a letter to the editor of a national newspaper, in which the author criticized the level of government funding for universities. The letter was attributed either to an official representative (the president of the student union) or an unofficial representative (an ordinary university student). Furthermore, the author used either collective language or personal language. After reading the letter, the participants evaluated the extent to which they thought the letter would be effective in terms of changing public opinion, the extent to which they had positive regard for the author, and the extent to which they believed the group would feel well represented by the letter.

On the basis of the social identity perspective, we expected that those who identified strongly as a university student would be more positive about the letter overall (i.e. they would see the letter to be more effective, they would be more positive about the author, and they would feel better represented) than would those who have weak identification as a university student (Hypothesis 1). We also predicted, however, that the effects of identification would be moderated by the type of language the advocate used. On the basis of work on social identity and categorization threat, we speculated that low identifiers would prefer advocates to use personal rather than collective language (Hypothesis 2). In contrast, we expected that high identifiers would rate advocates more favorably when they used collective rather than personal language (Hypothesis 3).

Given the lack of previous research and theory relating to the distinction between official and unofficial advocates, no strong predictions could be made with regard to how this variable might interact with language. However, on the basis of the arguments described above, we tentatively predict that participants would be more sensitive to the rhetorical strategies of official than of unofficial advocates. Thus, the effects of language described in Hypotheses 2 and 3 might be particularly pronounced for official (as opposed to unofficial) representatives (Hypothesis 4).

\section{Method}

\section{Participants and design}

A total of 187 Australian undergraduate psychology students participated for course credit. The sample consisted of 39 males and 148 females $(M=20.29$ years of age). The study was a 2 (Advocate Type: official versus unofficial) $\times$ 2 (Language: collective versus personal) $\times 2$ 
(Identification: low versus high) betweensubjects design. Participants were randomly allocated to the levels of the two manipulated variables: advocate type and language. Group identification was a measured variable.

\section{Procedure}

Participants were told that the study was examining attitudes toward student issues. To obtain a general gauge of participants' attitudes toward government funding for universities, participants first rated the extent to which they agreed with the statement: 'University students get a good deal in terms of government funding for university education' ( 1 = strongly disagree, 7 = strongly agree). Participants then completed a three-item identification scale: 'Being a university student is an important part of my self-image'; 'I identify as a university student'; and 'I have a lot in common with other university students' $(1=$ strongly disagree, $7=$ strongly agree; $\alpha=.75$ ).

Participants were then given what they were led to believe was an authentic letter to the editor of a nationally distributed broadsheet newspaper (in fact the letter was scripted by the experimenters). In each condition, the letter presented arguments against recent cuts in higher education and increased fees for students. Type of advocate was manipulated by attributing the letter to either an ordinary student (unofficial advocate) or to the President of the National Union of Students (official advocate). The name of the author of the letter (D. Henderson) was such that their gender was ambiguous.

Language was manipulated in the letters such that for half of the participants the author was writing on behalf of all students (collective language), and for the other half the author was writing on behalf of themselves (personal language). Collective versus personal language was manipulated using the following passage (personal language in parentheses):

On behalf of every university student in Australia [As a university student], I would like to express the disgust and cynicism that we [I] feel when we [I] hear politicians sprout about their commitment to the higher education system. We students [I] have witnessed savage cuts to education funding while at the same time being expected to pay hefty up-front fees and/or HECS. It is clear to each and every one of us [me] that the financial contribution that we [I] now make to our [my] education is not for the purposes of improving or even simply maintaining higher education standards. Rather, we are [I am] paying through the nose so that the Federal government can cut public funding and walk away, leaving behind a higher education system that we all [I] fear is becoming an international joke.

After reading the letter, participants rated the extent to which the author 'claims to be speaking on behalf of students', and the extent to which the author 'claims to be speaking only for themselves' ( $1=$ not at all, $7=$ very much $)$. After reverse-scoring the second item, these measures were combined to form a check on the manipulation of language $(\alpha=.83)$.

Participants then completed a short questionnaire that measured evaluation of the author (positive regard), evaluation of the message (effectiveness), and perceived representativeness of the comments. Positive regard was measured by asking the extent to which they thought the author was: trustworthy, open-minded, likable, interesting, and nice $(1=$ not at all, $7=$ very much; $\alpha=.81$ ). Effectiveness was measured by asking 'How persuasive do you think the letter will be for people who are not students?', and 'How effective do you think the letter will be in changing public opinion?' $(1=$ not at all, $7=$ very much; $\alpha=.73)$. Finally, representativeness was measured by asking participants the extent to which they thought most university students would 'feel comfortable with', 'agree with', and 'feel represented by' the author's comments $(1=$ not at all, $7=$ very much; $\alpha=.87)$.

To check whether positive regard, effectiveness, and representativeness represent discrete constructs and not a single underlying dimension, a factor analysis was conducted on these items using principal components extraction with direct oblimin rotation. As expected, a simple three-factor solution emerged, with the first factor comprising the five positive regard items (eigenvalue $=4.46,44.59 \%$ of variance explained), the second factor comprising the three representativeness items (eigenvalue = $1.41,14.10 \%$ of variance explained), and the 
third factor comprising the two effectiveness items (eigenvalue $=1.10,11.04 \%$ of variance explained). Intercorrelations among factors ranged from .35 to .45 .

\section{Results}

Analyses were conducted using 2 (Advocate Type: official versus unofficial) $\times 2$ (Language: collective versus personal) $\times 2$ (Identification: low versus high) analyses of variance (ANOVAs). ${ }^{1}$ Participants were categorized as high $(M=5.73)$ or low identifiers $(M=3.84)$ based on a median split. It is, of course, possible that low and high identifiers would have different attitudes regarding government funding for universities, and that this difference might have an effect on the results. However, preliminary analyses showed this was not the case. On the question of whether university students get 'a good deal' from the government, low $(M=3.70)$ and high identifiers $(M=3.76)$ did not differ $\left(F(1,180)=0.06, p=.82, \eta^{2}=.00\right)$. Thus, we assumed any effects of identification to be independent of pre-existing attitudes or politics.

\section{Manipulation check}

In line with the language manipulation, participants in the collectivist language condition perceived the author to be speaking on behalf of the group $(M=5.92)$ more than did those in the personal language condition $(M=4.22)$ $\left(F(1,180)=65.99, p<.001, \eta^{2}=.27\right)$. No other main effects or interactions emerged on this measure.

Positive regard In line with Hypothesis 1, a main effect of identification emerged such that high identifiers $(M=4.32)$ had greater positive regard for the advocate than did low identifiers $(M=4.01)\left(F(1,180)=4.72, p=.031, \eta^{2}=.03\right)$. This main effect, however, was qualified by a marginally significant interaction between identification, type of advocate, and language $\left(F(1,180)=3.48, p=.064, \eta^{2}=.02\right) \quad($ see Table 1). Follow-up analyses revealed that, for high identifiers, there were no significant main effects or interactions. In contrast, for low identifiers, a significant interaction emerged between type of advocate and language $(F(1$, $\left.180)=5.53, p=.020, \eta^{2}=.03\right)$.

Consistent with Hypothesis 2, analyses of simple main effects showed that, when evaluating official representatives, low identifiers preferred those who used personal language $(M=4.23)$ to those who used collective language $(M=3.66)(F(1,180)=5.30, p=.022$, $\left.\eta^{2}=.03\right)$. In contrast, they did not discriminate between unofficial representatives depending on whether they used personal $(M=3.97)$ or collective language $(M=4.26),(F(1,180)=$ $\left.1.17, p=.28, \eta^{2}=.01\right)$, a result that is consistent with Hypothesis 4.

Effectiveness Consistent with Hypothesis 1, high identifiers $(M=3.69)$ saw the message to

Table 1. Evaluations of advocate as a function of identification, advocate type, and language

\begin{tabular}{|c|c|c|c|c|c|c|c|c|}
\hline & \multicolumn{4}{|c|}{ Low identifiers } & \multicolumn{4}{|c|}{ High identifiers } \\
\hline & \multicolumn{2}{|c|}{$\begin{array}{c}\text { Official } \\
\text { representative }\end{array}$} & \multicolumn{2}{|c|}{$\begin{array}{l}\text { Unofficial } \\
\text { representative }\end{array}$} & \multicolumn{2}{|c|}{$\begin{array}{c}\text { Official } \\
\text { representative }\end{array}$} & \multicolumn{2}{|c|}{$\begin{array}{l}\text { Unofficial } \\
\text { representative }\end{array}$} \\
\hline & Collective & Personal & Collective & Personal & Collective & Personal & Collective & Personal \\
\hline Positive regard & $\begin{array}{c}3.66 \\
(1.06)\end{array}$ & $\begin{array}{c}4.23 \\
(1.06)\end{array}$ & $\begin{array}{c}4.23 \\
(0.66)\end{array}$ & $\begin{array}{c}3.97 \\
(1.03)\end{array}$ & $\begin{array}{c}4.24 \\
(0.73)\end{array}$ & $\begin{array}{c}4.23 \\
(0.91)\end{array}$ & $\begin{array}{c}4.34 \\
(0.97)\end{array}$ & $\begin{array}{c}4.47 \\
(0.84)\end{array}$ \\
\hline Effectiveness & $\begin{array}{c}2.67 \\
(1.28)\end{array}$ & $\begin{array}{c}3.28 \\
(1.32)\end{array}$ & $\begin{array}{c}3.62 \\
(1.15)\end{array}$ & $\begin{array}{c}3.15 \\
(1.36)\end{array}$ & $\begin{array}{c}3.80 \\
(1.14)\end{array}$ & $\begin{array}{c}3.20 \\
(0.99)\end{array}$ & $\begin{array}{c}3.95 \\
(1.19)\end{array}$ & $\begin{array}{c}3.91 \\
(1.07)\end{array}$ \\
\hline Representativeness & $\begin{array}{c}4.90 \\
(1.25)\end{array}$ & $\begin{array}{c}5.15 \\
(0.73)\end{array}$ & $\begin{array}{c}5.20 \\
(0.98)\end{array}$ & $\begin{array}{c}4.97 \\
(1.04)\end{array}$ & $\begin{array}{c}5.38 \\
(0.68)\end{array}$ & $\begin{array}{c}4.83 \\
(0.97)\end{array}$ & $\begin{array}{c}5.44 \\
(1.25)\end{array}$ & $\begin{array}{c}5.58 \\
(0.75)\end{array}$ \\
\hline
\end{tabular}

Note: Numbers in parentheses are standard deviations. 
be more effective overall than did low identifiers $(M=3.18)(F(1,179)=9.27, p=.003$, $\left.\eta^{2}=.05\right)$. Unexpectedly, unofficial advocates $(M=3.66)$ were also seen to be more effective overall than were official advocates $(M=3.22)$ $\left(F(1,179)=5.85, p=.017, \eta^{2}=.03\right)$. However, these main effects were qualified by a significant interaction between identification, type of advocate, and language $(F(1,179)=5.44, p=$ $.021, \eta^{2}=.03$ ) (see Table 1 ). As for ratings of positive regard, no significant main effects or interactions emerged for high identifiers. For low identifiers, however, there was a significant interaction between type of advocate and language $\left(F(1,179)=6.03, p=.015, \eta^{2}=.03\right)$.

Consistent with Hypothesis 2, analyses of simple main effects showed that low identifiers believed official representatives were more effective when they used personal language $(M=3.28)$ than when they used collective language $(M=2.67)(F(1,179)=4.66, p=.032$, $\left.\eta^{2}=.02\right)$. There was no evidence that low identifiers perceived the effectiveness of unofficial representatives to be different depending on whether they used personal $(M=3.15)$ or collective language $(M=3.62)(F(1,179)=1.83$, $\left.p=.18, \eta^{2}=.01\right)$, a result that is consistent with Hypothesis 4.

Representativeness As for ratings of positive regard and effectiveness, a significant three-way interaction emerged between identification, type of advocate, and language $(F(1,180)=$ $4.00, p=.047, \eta^{2}=.02$ ) (see Table 1). On this occasion, there were no significant main effects or interactions for low identifiers. For high identifiers, on the other hand, there was a significant interaction between type of advocate and language $(F(1,179)=4.01, p=.047$, $\left.\eta^{2}=.02\right)$. Consistent with Hypothesis 3, high identifiers believed the group would feel better represented by an official advocate when they used collective language $(M=5.38)$ than when they used personal language $(M=4.83)(F(1$, $\left.180)=4.31, p=.039, \eta^{2}=.02\right)$. On the other hand, in line with Hypothesis 4, there was no evidence that high identifiers perceived differences in the extent to which the unofficial advocate represented the group well depending on whether they used personal $(M=5.58)$ or collective language $(M=5.44)(F(1,180)=$ $\left.0.54, p=.46, \eta^{2}=.00\right)$.

\section{Discussion}

The current data revealed no simple prescriptions as to when advocacy will be perceived to be successful and when it will not. Rather, a complex but consistent relationship emerged between the type of advocate, the type of language they used, and the extent to which people identified with their group.

Overall, rhetorical styles that emphasized the collective ('we believe') were evaluated no more positively than were rhetorical styles that emphasized a personal viewpoint ('I believe'). One possible reason for the lukewarm manner in which such rhetoric was received is that collective language does not take into account the differences that exist among group members. Not all people would necessarily feel comfortable being categorized as a group member, because the group does not form an important part of their self-concept. For these people, there might emerge a feeling of discomfort stemming from the fact that they are being spoken for, but in a way that they do not completely endorse.

Evidence for such a process can be seen in the moderating role of identification. On measures of effectiveness and positive regard, the pattern was the same. Overall, low identifiers evaluated official advocates more positively when they used personal rather than collective language and they believed official advocates were more effective in promoting change when they used personal rather than collective language. There was no evidence, however, that high identifiers viewed the advocates differently on these measures depending on the type of language used. On measures of the extent to which participants thought the group as a whole would feel well represented by the comments, the pattern was slightly different. On this measure (based on what participants believed others would think) high identifiers believed that the group would feel better represented by official advocates using collective 
rather than personal language, whereas low identifiers did not differ between the rhetorical styles. Overall, the pattern of results shows that, when high identifiers expressed a preference for the type of rhetorical style official advocates should use (i.e. on the representativeness measure), it was in favor of collective language. In contrast, when low identifiers expressed a preference (i.e. on ratings of effectiveness and positive regard), it was in favor of personal language.

Such a finding makes sense from a social identity perspective. According to this perspective, any action that draws attention to a group membership potentially leads to the process of self-categorization. The more group members identify with a salient group, the more they will define themselves according to their social identity and the less they will identify themselves according to their idiosyncratic personal identity (Turner, 1991; Turner et al., 1987). A simple extension of this idea is that high identifiers should be more comfortable with collective language, because they are being categorized in a way that is consistent with how they define themselves-as a group member. Low identifiers, on the other hand, might feel a degree of categorization threat, because the way they are being categorized by the advocate does not map on to how they define themselves (Barreto \& Ellemers, 2002; Branscombe et al., 1999). For this reason, they may prefer that collective action be pursued as a series of individual voices (the anecdotal approach) rather than as a collective voice.

This finding runs counter to many stereotypes about what collective action looks like. Frequently, group-based interests are represented and articulated by official advocates who are explicitly invested with the power to speak on behalf of the group. On the surface, the notion of an official representative relying on first-person rhetorical strategies seems to run counter to role expectations. And yet this is precisely the type of strategy that low identifiers respond most positively to. When an official advocate uses collective language, low identifiers rate them relatively poorly and see them to be relatively ineffective. In fact, on ratings of message effectiveness and positive regard toward the speaker, the lowest ratings of all the conditions emerged when low identifiers were presented with an official advocate using collective language.

It is interesting to speculate on what implications this might have for collective action. Research on minority influence (e.g. Mugny \& Perez, 1991) shows that to be an effective agent of social change, groups should present a united, consistent message. However, when engaged in collective action, group members might experience a conflict between (a) needing to homogenize with other group members in order to maximize the influence and political effectiveness of their message, and (b) needing to protect against categorization threat (see also Brewer, 1991; Hornsey \& Jetten, 2004; Simon, 1997, for related discussions of the need for individual distinctiveness within groups). This tension might be particularly strong among those for whom the group is not central to their self-concept. Faced with what amounts to an irreconcilable conflict, it would be understandable if people psychologically withdrew from collective forms of protest and relied on individualistic strategies instead. This alienation of low identifiers comes at an obvious cost, because it is these people who must be energized and harnessed if collective action is to reach the type of critical mass that would be expected to bring about change.

Before concluding, two comments should be made in relation to the type of advocate. First, the effect of identification and rhetorical style only emerged for official advocates. For unofficial advocates, there appeared to be less concern about the type of rhetorical style used. As explained earlier, one possible explanation for this result is that official representatives are seen, by virtue of their senior role, to have psychologically separated themselves from the rank-and-file members. As a result, their claims to speak on behalf of all group members arouses more resentment among low identifiers than when similar claims are made by unofficial, emergent leaders within the group. Whereas high identifiers might feel happy to be homogenized as a member of the collective- 
and indeed might even see such rhetorical strategies as consistent with the role of the official advocate-low identifiers might feel doubly alienated by such language. Not only are they being categorized in a way that is not consistent with their self-definition, they are being categorized as such by one of them. An alternative explanation, however, is that people simply are not as vigilant with regard to the rhetorical choices of unofficial advocates, because relative to official representatives they might be seen as less careful and strategic in their speech. This relative naiveté with regard to their rhetorical 'choice' could mean that unofficial advocates are forgiven for their enthusiastic, collective language in a way that official representatives are not. Future research should address the psychological underpinnings of the interaction between language and advocate type, with a broader view to examining in more detail the previously underexplored differences between official and unofficial advocates.

The second finding that deserves comment is that unofficial representatives were seen to be more effective overall than were official representatives. Although this main effect was qualified by identification and language, the overall trend deserves some comment. Given that official advocates are employed, at least in part, to prosecute the interests of the group, it is striking that they are generally regarded to be less effective than are rank-and-file members who speak on behalf of the group. The persuasion literature throws up some ideas as to why this might be the case. Perceived trustworthiness is often viewed as the most important criterion for credibility (Cronkhite \& Liska, 1976; Perloff, 1993). One factor that can compromise this trust is when we know that a person has a vested interest in their message (Eagly, Wood, \& Chaiken, 1978). When we expect that a person will hold a particular opinion because their role or group membership demands it, then we infer certain biases that undermine our confidence in the veracity of their message. Intuitively, this makes sense. If we believe that somebody is motivated to not look objectively at an issue (knowledge bias) or that the pressures of the situation might lead them to disguise unpalatable truths (reporting bias), we are less likely to trust them. Given that the representative's role is a very partisan one where the single objective is to prosecute the interests of the group, it would be reasonable to expect that a representative would always be operating-quite consciously-with bias. Thus, it is possible that a message stemming from an official advocate is more likely to be dismissed as biased than would a message from a rank-and file member, both by the general public and by their own constituency. If this overall tendency to perceive unofficial advocates to be more effective than official advocates proved to be robust, it would seem a sensible next step to measure attributions regarding the motives for their comments, and to see whether they mediate the effect.

In conclusion, the need for group advocates to demonstrate strength through unity and the politically 'instinctual' appreciation for the power of identifying with the group, often leads to the rhetorical strategy of speaking for all (the group). A preliminary reading of the literature on leadership lends suggestive support for such an approach; the strategic use of inclusive language could help locate the speaker as a central member of the group and thus maximize his or her credibility and persuasive power (e.g. Hogg, 2001; Reicher \& Hopkins, 1996a, 1996b). But the current research suggests a more complicated link between language and outcomes for official advocates. Whereas inclusive language might be seen as appropriate in the eyes of high identifiers (and, theoretically, in the eyes of third parties), low identifiers might baulk at being spoken on behalf of. To reduce the risk of alienating marginal members or those who simply feel too much the weight of inclusivity, the optimal rhetorical strategy, in some circumstances, may be to use anecdotal personal language to articulate the beliefs and aspirations of the wider group. 


\section{Note}

1. It should be noted that the interpretation of the effects reported below do not change regardless of whether we covary out age and sex. Furthermore, the interpretation of the effects remains the same regardless of whether the analyses are conducted through ANOVA or through regression. Thus, for ease of reporting and interpretation, we have chosen to report the results through ANOVA using a median split on identification.

\section{Acknowledgments}

This paper was supported by a postdoctoral fellowship awarded to the first author by the Australian Research Council. We would like to thank Steve Reicher for his very helpful comments on an earlier version of this manuscript.

\section{References}

Barreto, M., \& Ellemers, N. (2002). The impact of respect versus neglect of self-identities on identification and group loyalty. Personality and Social Psychology Bulletin, 28, 629-639.

Branscombe, N., \& Ellemers, N. (1998). Coping with group-based discrimination: Individualistic versus group-level strategies. In J. Swim \& C. Stangor (Eds.), Prejudice: The target's perspective (pp. 243-266). San Diego, CA: Academic Press.

Branscombe, N., Ellemers, N., Spears, R., \& Doosje, B. (1999). The context and content of social identity threat. In N. Ellemers, R. Spears, and B. Doosje (Eds.), Social identity: Context, commitment, content (pp. 35-58). Oxford, UK: Blackwell.

Brewer, M. (1991). The social self: On being the same and different at the same time. Personality and Social Psychology Bulletin, 17, 475-482.

Brewer, M. B., \& Gardner, W. (1996). Who is this 'We'? Levels of collective identity and self representations. Journal of Personality and Social Psychology, 71, 83-93.

Cronkhite, G., \& Liska, J. (1976). A critique of factor analytic approaches to the study of credibility. Communication Monographs, 43, 91-107.

Eagly, A. H., Wood, W., \& Chaiken, S. (1978). Causal inferences about communicators and their effect on opinion change. Journal of Personality and Social Psychology, 36, 424-435.

Fielding, K. S., \& Hogg, M. A. (1997). Social identity, self-categorization, and leadership: A field study of small interactive groups. Group Dynamics: Theory, Research, and Practice, 1, 39-51.

Hains, S. C., Hogg, M. A., \& Duck, J. M. (1997) Self-categorization and leadership: Effects of group prototypicality and leader stereotypicality. Personality and Social Psychology Bulletin, 23, 1087-1100.

Haslam, S. A., McGarty, C., Brown, P. M., Eggins, R. A., Morrison, B. E., \& Reynolds, K. J. (1998). Inspecting the emperor's clothes: Evidence that random selection of leaders can enhance group performance. Group Dynamics: Theory, Research, and Practice, 2, 168-184.

Haslam, S. A., Turner, J. C., Oakes, P. J., McGarty, C., \& Hayes, B. K. (1992). Context dependent variation in social stereotyping I: The effects of intergroup relations as mediated by social change and frame of reference. European Journal of Social Psychology, 22, 3-20.

Hogg, M. A. (2001). A social identity theory of leadership. Personality and Social Psychology Review, 5, 184-200.

Hogg, M. A. (2002). Social identity. In M. R. Leary \& J. P. Tagney (Eds.), Handbook of self and identity (pp. 462-479). New York: Guilford.

Hogg, M. A., Hains, S. C., \& Mason, I. (1998). Identification and leadership in small groups: Salience, frame of reference, and leader stereotypicality effects on leader evaluations. Journal of Personality and Social Psychology, 75, 1248-1263.

Hopkins, N., \& Reicher, S. (1996). The construction of social categories and processes of social change: Arguing about national identities. In G. M. Breakwell \& E. Lyons (Eds.), Changing European identities: Social psychological analyses of social change (pp. 69-93). Oxford, UK:

Butterworth-Heinemann.

Hornsey, M. J, \& Hogg, M. A. (2000a). A comparison of the mutual intergroup differentiation and common ingroup identity models of prejudice reduction. Personality and Social Psychology Bulletin, 26, 242-256.

Hornsey, M. J., \& Hogg, M. A. (2000b). Assimilation and diversity: An integrative model of subgroup relations. Personality and Social Psychology Review, 4, 143-156.

Hornsey, M. J., \& Hogg, M. A. (2000c). Intergroup similarity and subgroup relations: Some implications for assimilation. Personality and Social Psychology Bulletin, 26, 948-958.

Hornsey, M. J., \& Hogg, M. A. (2002). The effects of status on subgroup relations. British Journal of Social Psychology, 41, 203-218. 
Hornsey, M. J., \& Jetten, J. (2003). Not being what you claim to be: Impostors as sources of group threat. European Journal of Social Psychology, 33, 639-657.

Hornsey, M. J., \& Jetten, J. (2004). The individual within the group: Balancing the need to belong with the need to be different. Personality and Social Psychology Review, 8, 248-264.

Hornsey, M. J., Oppes, T., \& Svensson, A. (2002). 'It's ok if we say it, but you can't': Responses to intergroup and intragroup criticism. European Journal of Social Psychology, 32, 293-307.

Kelly, C., \& Breinlinger, S. (1996). The social psychology of collective action: Identity, injustice and gender. London: Taylor \& Francis.

Maass, A., \& Clark, R. D., III (1984). Hidden impact of minorities: Fifteen years of minority influence research. Psychological Bulletin, 95, 428-450.

Mackie, D. M., Worth, L. T., \& Asuncion, A. G. (1990). Processing of persuasive in-group messages. Journal of Personality and Social Psychology, 58, 812-822.

Moscovici, S. (1976). Social influence and social change. London: Academic Press.

Mugny, G., \& Perez, J. A. (1991). The social psychology of minority influence. Cambridge, UK: Cambridge University Press.

Mummendey, A., \& Wenzel, M. (1999). Social discrimination and tolerance in intergroup relations: Reactions to intergroup difference. Personality and Social Psychology Review, 3, 158-174.

Perloff, R. M. (1993). The dynamics of persuasion. Hillsdale, NJ: Erlbaum.

Platow, M. J., Reid, S., \& Andrew, S. (1998). Leadership endorsement: The role of distributive and procedural behavior in interpersonal and intergroup contexts. Group Processes $\mathcal{E}$ Intergroup Relations, 1, 35-47.

Rapley, M. (1998). 'Just an ordinary Australian': Self-categorization and the discursive construction of facticity in 'new racist' political rhetoric. British Journal of Social Psychology, 37, 325-344.

Reicher, S., \& Hopkins, N. (1996a). Seeking influence through characterizing self-categories: An analysis of anti-abortionist rhetoric. British Journal of Social Psychology, 35, 297-311.

Reicher, S., \& Hopkins, N. (1996b). Self-category constructions in political rhetoric: An analysis of Thatcher's and Kinnock's speeches concerning the British miners' strike (1984-5). European Journal of Social Psychology, 26, 353-371.

Reicher, S., \& Hopkins, N. (2001). Psychology and the end of history: A critique and a proposal for the psychology of social categorization. Political Psychology, 22, 383-407.
Sani, F., \& Reicher, S. (1998). When consensus fails: An analysis of the schism within the Italian Communist Party. European Journal of Social Psychology, 28, 623-645.

Sani, F., \& Reicher, S. (2000). Contested identities and schisms in groups: Opposing the ordination of women as priests in the Church of England. British Journal of Social Psychology, 39, 95-112.

Simon, B. (1997). Self and group in modern society: Ten theses on the individual self and the collective self. In R. Spears, P. J. Oakes, N. Ellemers, \& S. A. Haslam (Eds.), The social psychology of stereotyping and group life (pp. 318-335). Oxford, UK: Blackwell.

Simon, B., \& Klandermans, B. (2001). Politicized collective identity: A social psychological analysis. American Psychologist, 56, 319-331.

Tajfel, H., \& Turner, J. C. (1979). An integrative theory of intergroup conflict. In W. G. Austin \& S. Worchel (Eds.), The social psychology of intergroup relations (pp. 33-47). Monterey, CA: Brooks/Cole.

Turner, J. C. (1991). Social influence. Buckingham, UK: Open University Press.

Turner, J. C. (1999). Some current issues in research on social identity and self-categorization theories. In N. Ellemers, R. Spears, \& B. Doosje (Eds.), Social identity: Context, commitment and content (pp. 6-34). Oxford, UK: Blackwell.

Turner, J. C., \& Haslam, S. A. (2001). Social identity, organizations, and leadership. In M. E. Turner (Ed.), Groups at work: Theory and research (pp. 25-65). Mahwah, NJ: Erlbaum.

Turner, J. C., Hogg, M. A., Oakes, P. J., Reicher, S. D., \& Wetherell, M. S. (1987). Rediscovering the social group: A self-categorization theory. Oxford, UK: Blackwell.

Turner, J. C., Oakes, P. J., Haslam, S. A., \& McGarty, C. (1994). Self and collective: Cognition and social context. Personality and Social Psychology Bulletin, 20, 454-463.

van Knippenberg, A., Lossie, N., \& Wilke, H. (1994). In-group prototypicality and persuasion:

Determinants of heuristic and systematic message processing. British Journal of Social Psychology, 33, 280-300.

van Vugt, M., \& de Cremer, D. (1999). Leadership in social dilemmas: The effects of group identification on collective actions to provide public goods. Journal of Personality and Social Psychology, 76, 587-599.

Paper received 18 December 2003; revised version accepted 19 October 2004. 


\section{Biographical notes}

MATTHEW J. HORNSEY is a lecturer at the University of Queensland, Australia, and the Director of the Centre for Research on Group Processes. His research focuses on the social psychology of intergroup relations, identity threat, and the tension between individual and group will.

LEDA BLACKWOOD is a postgraduate student at the University of Queensland. Her research interests include social influence on political beliefs and action.
ANNE O'BRIEN is a postdoctoral researcher at the University of Exeter, UK. Her research utilizes a social identity perspective to understand organizational issues such as adjustment to organizational change, workplace stress and effective ways of building sustainable diverse organizations. 